\title{
Research on the Legal System of the Export Credit Insurance in China's Foreign Trade
}

\author{
Nannan Qu \\ Shandong University of Finance and Economics, Jinan, China \\ Email: qunannanfx@163.com
}

Received 24 July 2015; accepted 19 September 2015; published 22 September 2015

Copyright ( 2015 by author and Scientific Research Publishing Inc.

This work is licensed under the Creative Commons Attribution International License (CC BY). http://creativecommons.org/licenses/by/4.0/

(c) (;) Open Access

\begin{abstract}
With China's export trade launches extensively, and the relevant trade systems obtain the unceasing development, but the credit insurance system is not perfect, such as the speed and the scale of China's export credit insurance system are far from the requirements of the international trade development and the related legal system requires to be further strengthened. This article analyzes the export credit insurance's concept, characteristics and functions as well as problems of the related legal system of China's export credit insurance at the present stage, and proposes some suggestions to strengthen China's export credit insurance system in order to promote the improvement of related legal system, better for China's export trade services.
\end{abstract}

\section{Keywords}

Export Credit Insurance, Credit Insurance System, Credit Insurance's Concept, The Legal System, Improvement of Legal System

\section{Introduction: An Overview of Export Credit Insurance}

\subsection{The Concept of Export Credit Insurance}

Export credit insurance is a common practice of international trade and it origins in the middle of the 19th century in Europe. With active commodity economy, after 150 years of development, it has extended to more than 70 countries and regions. Export credit insurance, also known as foreign trade insurance in some countries, is occurring in the commodity exporting or related economic activities. The insurer (insurance companies operate export credit insurance business) and the insured (the exporters or banks provide credit to the foreign buyers) sign an insurance agreement. According to the agreement, the insured pay insurance gold to the insure, and the insurer pay the economic losses caused by the insured buy goods or lend money to foreign buyers due to the buyer's credit and related factors [1]. 
What is the export credit insurance? From the literal meaning, we can infer that the export credit insurance is an insurance related export behavior. There are a lot of discussions on this concept for a more in-depth definition; the difference between the different definitions of the concept reflects the different understanding of the concept in the current theory circle.

Xiao Zhaoqing defined export credit insurance as "export goods to the exporters on credit terms and to bear a compensation payment of insurance when the buyer fails to pay [2]. Xin Xin and Ding Yong defined it as "national government set up export credit agencies or authorized and entrusted to the specific financial and insurance sector in accordance with the law; and it is a special policy of insurance business with specialized operation", and further discussed it as "the insurer enters into an insurance contract with the insured (the exporters) of the country according to the provisions of the laws and regulations of export credit insurance and insurance, the insurer pays the insurance premiums and obtain the insurance policy, the insurer undertake economic compensation at the occurrence of insured liability within the scope of commercial risks and political risks, and the loss of the purchase price as a result of this.” [3]. The task group "using the finance method to promote the export” of the Ministry of Foreign Trade and Economic Cooperation defined the export credit insurance as "a credit insurance to take foreign buyers' credit risk as insurance object in export trade. It is a kind of credit insurance business that the insurer accepts insurance the loss of the domestic exporters because of the business risk of the importers or the political risk of the importing countries in the process of exporting business.” [4]. Mu Linlin defined it as "an insurance agreement signed by the insurer and the insured occurring in commodity exports or related economic activities: according to the contract of insurance, the insured pays insurance premium and the insure compensate the economic losses caused by the insured sell on credit to the foreign buyers or loans money due to the buyers' credit and related factors under the insurance contract.” [5].

As previously mentioned, export credit insurance is a kind of insurance underwriting exporters' risk of loss due to the importer of commercial risk or the importing country's political risk in the export process [6]. It is a political insurance business reserve nonprofit that countries promote the country's export trade, guarantee export enterprises’ safety exchange and provide insurance by the state finance.

\subsection{Characteristics of Export Credit Insurance}

\subsubsection{Obvious Policy Characteristics}

At present, Chinese scholars generally believe that the export credit insurance has a strong policy feature. So, the business goals cannot achieve the profit maximization, and should be in accordance with the government's guidance to support the export and to carry out the nonprofit or low profit business [7]. However, the main goal is not to profit does not mean that the export credit insurance institutions do not pursue economic benefits. On the contrary, the high risk in the export credit insurance requires that the export credit insurance institutions should strictly control the risk and strengthen the management, and strive to obtain the maximum benefits with the minimum cost.

\subsubsection{Both Underwriting Commercial Credit Risk, but Also to Cover the National Risk, with High Risk}

The risk of export credit insurance includes commercial credit risk and country risk. Commercial credit risk is also referred as the buyer's risk, which refers to the risk that the buyers of the non official subject breach contracts because of the commercial mistakes. While the national risk is the possibility of the occurrence in the international economic activities, and related to the national sovereignty, beyond the scope of the creditor's control and can cause economic losses. "National risk is one of the basic risks of export credit insurance, but also the risk that is not covered by the Business insurance company, because of its uncertainty and harmfulness. Therefore, compared with the business insurance company, the national risk has a huge influence to the export credit insurance companies.” [8].

\subsubsection{Government Involvement and Semi Official Nature}

Export credit insurance is a kind of insurance with high policy and needs the government to participate with the nature of the business objective and the risk of the underwriting and the subject of underwriting. The export credit insurance agency is usually set up by the government or to give financial support, and provides a variety of tax incentives, and the government is also the ultimate undertaker of risk. 


\section{Several Problems of the Export Credit Insurance in China}

\subsection{Laws and Regulations Are Not Perfect}

Compared with the western developed countries, export credit insurance system develops later in China. It is still in initial stage, especially the laws and regulations about export credit insurance still exist a lot of blank so far. Existing legal norms made clear provisions of export credit insurance are still very few. "Foreign Trade Law" (revised in 2004) set principle provisions to China's export credit insurance, it pointed out: "Our country promote the development of foreign trade mainly through export credit, credit insurance, tax rebates and other ways.” [9]. It makes a clear rule on the role and status of China's export credit insurance the first time. The "SME Promotion Law" (2003) only briefly pointed out: "related political and financial departments of our country should carry out export credit insurance, credit and other related business to promote China's small and medium sized enterprises to enter overseas market." [10].

Take a comprehensive view of the countries with developed export credit insurance business in Europe, America and Asia, they all formulate special export credit insurance laws and regulations, and policy export credit agencies of the most countries are beyond the constraints from ordinary commercial banks or insurance law, and to regulate political export credit insurance system with separate laws and regulations. Such as Japan's "trade and investment insurance law", the United Kingdom's “export and investment guarantee law”, etc.

\subsection{Application of Law}

The existing problems on the law applicable to the contract of export credit insurance are relatively serious. According to the relevant provisions of the "insurance law", the existing "insurance law" has legal effect only for commercial insurance organizations and their acts and excludes the export credit insurance. Therefore, the relevant provisions of the insurance contract in the "insurance law" are not applicable to the legal relationship of export credit insurance. "Foreign trade law" and other relevant legal norms are also limited to the principle and general description, there are no substantive provisions. And the relevant legislation of the export credit insurance contract is blank. In the process of dealing with the disputes of export credit insurance, the judicial circles often cannot make a reasonable choice of the applicable law. Some judges make the wrong decision on the basis of the legal relationship of export credit insurance in the "security law". Some judges rule on the basis of the "contract law", often do not take into account the influence of the "insurance" in the export credit.

\subsection{Policy Support Is Not Enough}

China's export credit insurance lack the support of relevant policies, the existing legal norms has not clear provisions of the export credit insurance support. In developed countries, the expenses, legal claims, business income and the revenue of claims of the export credit insurance institutions are typically incorporated into the scope of state budget, go on annual audit, and protect it use the relevant legislations. Such as annual loan amount, insurance amount and guarantee amount of the Import and Export Bank in the United States need the congress's approval; France predicts the expense of export credit insurances according to the agency's annual business income and reasonable payment in arrears and the recovery amount in France each year, and incorporated into the national budget.

\subsection{Lack of Insurance Awareness of Export Enterprises}

At present, the export enterprises, especially for small and medium enterprises which are engaged in the shortterm trade, the enthusiasm of insurance is relatively low and the insurance consciousness is weak. The reason is the transaction of export enterprises in China use a large number of the letter of credit for a long time, lead to a part of enterprises' operating tendency. The concept sales goods with the commercial credit have not yet formed. At the same time, due to the export credit insurance business in China is still in the initial stage, many enterprises are also lack sufficient knowledge to export credit insurance, even if there are people to understand, also often see the short and not its length, thinking more the transaction cost to the transaction income.

\section{The Perfection of the Legal System of China's Export Credit Insurance}

\subsection{Establishing and Improving the Laws and Regulations on the Export Credit Insurance}

From the point of view of foreign experience, they have one thing in common, that is the export credit insurance 
is established on the foundation regulations and framework regardless of the mode for export credit insurance business. Such as France released the government order in 1946 and in 1994; Italy’s Law No. 277 in 1977; Hong Kong's “the Hong Kong Export Credit Insurance Company Law” in 1966; Korea’s "the export insurance law", "the implementation of export insurance law" and "Implementing Regulations of Export Insurance Law" in 1992. They are all laws and regulations for the development of export credit insurance [11]. China can set up the legal norm of export credit insurance under the "foreign trade law" and "insurance law", and include the export credit insurance to the legislative plan.

We should consider establishing a sound and flexible way of insurance. At present, China's short-term export credit insurance business insurance use the principle of "unified insurance". The so-called unified insurance is to say that all of the export business, all business of export enterprises needs to deal with export credit insurance in a certain period of time or a certain regional market at a once. In this way, the advantages and disadvantages of the exporters are incorporated into the scope of insurance, so the insurance agency can spread the risk and expand the coverage of insurance business. However, this comprehensive policy is difficult to meet the diversifiable needs of enterprise.

For the sustainable development of long-term export credit insurance, China needs to innovate the underwriting model. To facilitate the export enterprises to insure, China's letter insurance should actively create underwriting model and optimize business processes. For large manufacturing enterprises export, China should launch simple underwriting model. For the production of small and medium-sized enterprises export commissioned by foreign trade companies, launched the proxy business underwriting model. We should introduce specific risk underwriting model for the special needs of enterprises.

\subsection{Improving the Legal Application of Export Credit Insurance Contract}

In the current insurance law of China, the general theory of the contract of insurance is also applicable to the constitute of export credit insurance contract. In accordance with the relevant provisions of the "insurance law" of our country, the insurer should determine the minimum payment amount of claims according to the existing data statistics and compensate balance payable in a full range of claims data to determine accurate amount of claims within 60 days of the receipt of other related information. Through the implementation of this insurance mechanism, it is effective to avoid the fraud based on the combination of the import and export of the insurance company’s. Many international credit insurance agencies usually use this approach.

\subsection{Improve the Funding Mechanism and Budget Management Mechanism}

To perfect the legal norm of China's export credit insurance, we also need to perfect the supplementary mechanism of the venture capital and the mechanism of the budget management, and strengthen the support to the export credit insurance. With reference to the international practice, to establish a reasonable insurance fund supplement mechanism and to set the addition of the amount of venture capital main refers to the export scale, the capable of operating of the insurance institutions and financial situation of the country, and to implement certain tax preferential policies for the export credit insurance, reflecting the policy support of state to the export credit insurance.

\section{Conclusion}

Export credit insurance plays a role which cannot be ignored to expand exports and achieve manufacturers with China continue to carry out international trade and accelerate integration with the world economy. It is an important policy means to accelerate the development of the foreign trade of China. We must speed up the process of the relevant legislation to better respond to the opportunities and challenges after joining in WTO based on the view of China's export credit insurance laws and regulations because they are not perfect and have other issues. We should take the essence of foreign countries based on the comparative study of the legal systems of the export credit insurance and discard the dross of it. We should establish a set of legal systems of the export credit insurance with Chinese characteristics, which is based on the reality of China.

\section{References}

[1] Yang, X.J. (2004) The Assessment of Country Risk of Export Credit Insurance-Theory. Method·Demonstration. Eco- 
nomic Science Press, Beijing, 13.

[2] Xiao, Z.Q. (2004) Export Credit and Insurance. China Business Press, Beijing, 1.

[3] Xin, X. and Ding, Y. (1999) Export Credit Insurance Discrimination. Modern Finance: Journal of Tianjin University of Finance and Economics, 5, 59-61.

[4] The Task Group (1996) "Using the Finance Method to Promote the Export” of the Ministry of Foreign Trade and Economic Cooperation, Export Credit Insurance: An Effective Means of Promoting Exports. International Business Daily, 8, 2.

[5] Mu, L.L. (1996) Export Credit and Insurance. Chinese Foreign Economic and Trade Press, Beijing, 51.

[6] Wang, W.D. and Li, X.F. (2006) Principle and Pragmatic of Export Credit Insurance. China Business Press, Beijing, 125.

[7] Zhao, X. (2007) Analysis of China’s Export Credit Insurance. North China Finance, 10, 36-38.

[8] Xu, X.H. and Chen, Q. (2004) Preliminary Study on the Risk of Export Credit Insurance in China. Journal of Chinese Insurance Management, 5, 28-29.

[9] (2004) The Standing Committee of the National People's Congress, the Foreign Trade Law of the People’s Republic of China, Article 53.

[10] (2003) The Standing Committee of the National People’s Congress, the SME Promotion Law of the People's Republic of China, Article 35.

[11] Zhao, M.X. (2010) The Reflection and Reconstruction of the Legal System of Credit Insurance in China. Law Press, Beijing, 247. 